\title{
Experiments in empire-building: Mendelian genetics as a national, imperial, and global agricultural enterprise
}

Berris Charnley

University of Exeter

Dr Berris Charnley

ESRC Centre for Genomics in Society (EGENIS),

Byrne House,

University of Exeter,

EX4 4PJ

Email: B.Charnley@exeter.ac.uk; Berris.Charnley@gmail.com.

Tel: +44-(0)1392-725125

Fax: +44-(0)1392-724676

\begin{abstract}
The first British geneticists framed the productive value of their work against national, international and colonial contexts. They drew on traditional links between nation, wheat and civilisation, promising rural stability and national security if only they could command the resources required to create new, agriculturally useful, varieties. Framing their new science in this manner allowed them to make claims on the public purse far beyond those of the normal patent bargain. With these funds they set about establishing new research institutes across the country and the globe. This paper follows the work of one of the most prominent early geneticists, Rowland Biffen, as he established new research centres in Britain and sought to export the same model of development to Kenya. In support of these activities, a public-service-
\end{abstract}


ethos view of Biffen's work appeared in the non-specialist press of the day. This public-service view of his work was one which aided Biffen's efforts to nationalise financial support for his new plant breeding program.

\section{Highlights}

- Rowland Biffen believed genetics would revolutionise agriculture.

- Genetics and geneticists have always been embedded in an international context.

- Biffen and his contemporaries believed genetics would benefit the British Empire.

- Early geneticists were adept at promoting their new science in the nonspecialist press.

\section{Keywords}

Rowland Biffen, Mendelism, Plant Breeding, Agriculture, Nation, Empire.

\section{Introduction}

As a matter of fact you are producing more than in the Argentine ... Given proper cultivation ... I can see no great difficulty in Kenya producing not only enough to feed itself, but to feed its native population as well. ${ }^{1}$

This was the somewhat surprising conclusion reached by Sir Rowland Biffen in his 1927 address to the white farming community of Kenya. One can imagine the farmers' surprise at being told their country produced wheat on a level with Argentina - one of the great wheat producing countries of the period. Our own surprise today 
may relate more to the attitude expressed by Biffen towards the "native population". However, the partially redeeming specifier that is missing from this quotation is wheat. At the time of Biffen's speech, wheat was a new crop in Kenya. ${ }^{2}$ The staple crop of most Kenyans was maize. It was part of Biffen's plan for the country's agriculture that an internal market for wheat consumption - one which included the "native population" - should stimulate the development of a wheat industry. The relationship between wheat and colonial development would, he hoped, be a symbiotic one. As settlers spread European culture, including novel concepts of land ownership and agricultural production, the increasingly civilised native population, so the thinking ran, would turn to eating wheat, thereby supporting the settlers' efforts at introducing the crop to the country. This pattern of development, now long forgotten, would have been familiar to Biffen's audience. ${ }^{3}$ It turned on the belief that civilisation was deeply associated with a preference for wheaten, and ideally, white bread. ${ }^{4}$ What is more, eating more wheat could raise a nation up from barbarity. Producing wheat in nation-sustaining quantities demanded that hunter-gatherer and foraging systems be replaced by high farming, preferably just like that conducted in the south east of Britain. Developing Kenya's agricultural land also meant civilising the population. Wheat was the key to both ambitions.

Biffen's belief in the civilising power of a thriving wheat industry was not restricted to recently acquired colonial outposts. In Britain too, Biffen believed the application of Mendelian science to wheat growing problems could deliver a thriving industry -- one that would undergird a stable and prosperous rural civilisation. To put this claim in language already introduced in this volume, Biffen made productivity claims about Mendelism's ability to deliver a new rural civilisation, at home and abroad. This outcome was important enough, Biffen felt, to warrant government 
funding. Looking back on these historical developments, one can see in operation a quite different conception of the "patent bargain" to that discussed so far in this volume. Conventionally, the patent bargain is a deal between the state and the inventor in which the state rewards an inventor's disclosure of a new invention with a limited monopoly over its sale. Biffen, who very much believed that Mendelism allowed him to invent new plants, felt that, rather than deserving a government mandated monopoly over his innovations in return for their disclosure, his work, instead, required direct government sponsorship. In other words, the national importance of the productivity claim Biffen made for Mendelism was, by his lights, and those of his many supporters, enough to justify direct government support that went far beyond the limited protection that patents might offer.

As we have already seen (in the survey paper earlier in this issue), during the nineteenth century the intangible value of new varieties came to be gauged through an intricate system of prize giving and public display. ${ }^{5}$ Biffen and his supporters became adept at making productivity claims for their Mendelian varieties in this context. Biffen's new varieties of wheat were displayed in public more often than most and these public appearances form the evidential base of this paper. The paper's first half focuses on Biffen's plans for the British wheat industry, especially the international dimensions of these plans. First, we will see that the international grain trade was the source of many problems for the British wheat industry. It was in this international context that Mendelians such as Biffen identified the problems that, they argued, Mendelism could solve. At the same time, it was from a range of international contacts in just these competing countries that Biffen gained the raw materials for his breeding program. Working in Britain, Biffen helped to create a string of institutes that aimed to deal with the problems brought by the international wheat markets, 
while simultaneously developing a network of international collaborators. Wheat production came to be part of a Mendelian empire of research institutes which sought to apply the new science. In the second half of the paper, we turn from this institutional empire to Biffen's plans for what he called "the agricultural empire". This was a new vision for the British Empire, one in which Britain would be situated at the heart of a colonial network of agricultural production that fed back to the centre. In the early 1920s, far from waning, many were expecting the British Empire to expand. In 1927, during a visit to Kenya, Biffen outlined his plan for the country's infant wheat industry. These plans reveal his ambitions to entirely nationalise the innovation process, from agricultural research station to farm field, and, in so doing, to stabilise the rural civilisations of both Britain and Kenya. Mendelian wheat breeding in Britain was truly an international affair upon which, Biffen felt, the stability of rural civilisation hinged.

\section{Wheat Breeding: A Matter of National Importance}

\subsection{The Grain Invasion}

During the 1890s the British wheat industry was severely depressed. ${ }^{6}$ The total number of acres devoted to wheat growing was in decline, from well over three million acres in the heyday of the agricultural boom of the 1860 s to below two million and falling in the late 1890s. Many farmers were turning wheat fields over to pasture, following the farmers' dictum for hard times, “down corn: up horn". When the price of corn was down, it was a good time to move over to cattle, either for meat or dairy. The decline in home grown wheat meant hard times for inland millers who increasingly had to pay transport costs to get imported wheat from the ports. There were also more subtle effects on rural life. As harvests became smaller, fewer workers 
were needed and this added to the on-going trend of rural depopulation, as many casual labourers left to find jobs in the expanding cities. These changes threatened a certain view of agrarian civilisation encapsulated in the phrase "high farming". Wheat farming was decidedly high farming; cattle, dairy and mixed farming were considered lowly activities in comparison. The location of high farming, in the south east, indicates where a great deal of this prejudice comes from: high farming was practised by the wheat barons and wealthy land owners of this area; animal farming took place in the provinces. ${ }^{7}$ In the 1890 s, it was high farming that was in crisis; mixed and dairy farming, however, were doing reasonably well. Arable land that had been turned over to pasture was increasingly used to produce milk for London. ${ }^{8}$

The area of land used for wheat production continued to shrink into the start of the twentieth century. The problem was one of foreign competition. The westward expansion of wheat growing in the US and Canada had led to a massive increase in wheat production, and surpluses were placed on the international grain markets. Improvements in storage and transport meant that American and Canadian farmers were now directly competing with their British counterparts. ${ }^{9}$ British farmers were at a disadvantage on two fronts. First, New World wheat, grown on the fertile prairies was cheaper to produce, especially given high labour costs in Britain. Secondly, this prairie wheat was imbued with a character called "strength", that was absent from British wheat. Essentially, this was the character that millers and bakers believed to be responsible for making a loaf fluffy and voluminous. At that time, fluffy white bread was rapidly becoming more popular than the traditional brown loaf. In line with this change in preference, strength had become the defining feature of a wheat variety's quality. American and Canadian wheat had more of this strength than British wheat, leading British millers and bakers to use more imported wheat, for which they paid 
higher prices in a market which had been generally driven downwards. ${ }^{10}$ The grain invasion (as the massive, late nineteenth-century increase in imports of grain has since been called) had two effects on British agriculture: the first was to undermine the price of weak British wheat; the second was further to concentrate the milling industry around the big ports. ${ }^{11}$ Together these two effects were draining life away from inland rural areas, as inland millers and wheat farmers were being driven out of business.

To Biffen, this was a tragedy. But it was a process that, he believe, could be reversed. Biffen reasoned that new varieties were the way forward. With new varieties at their disposal, farmers might return to wheat growing, as it became profitable again, and retake their foundational place in a flourishing rural economy. In a programmatic statement published in Nature in 1903, Biffen outlined the two chief directions he saw for improving British wheat. ${ }^{12}$ One possibility was to produce new disease resistant varieties, thereby increasing yield per acre by avoiding losses to disease. But, as Biffen explained two years later, British farmers were already growing more per acre than any other wheat growing area in the world. ${ }^{13}$ Although there were some small gains to be made from disease resistance, Biffen felt the real answer to the wheat growing industry's problems lay with stronger varieties. So while Biffen enjoyed early successes with disease resistance, his grander plan was for new strong wheat varieties. The two projects were, however, closely linked: Biffen's disease resistance work did a great deal to shore up his claims about the effectiveness of the new Mendelian breeding when he turned his attention to strength.

Throughout his career, Rowland Biffen claimed that the correct relationship between the agricultural and the scientific aspects in his discipline, agricultural science, was a serendipitous one. ${ }^{14}$ He advocated the view that agriculture was best 
aided by scientific research conducted unfettered by specific practical concerns. However, Biffen was still deeply committed to practical outcomes - as were important members of the government. David Lloyd George, in particular, first as Chancellor of the Exchequer and later as Prime Minister, underwrote Biffen's campaign to change plant breeding, agricultural science and, ultimately, British agriculture. ${ }^{15}$ When Biffen promoted his views on plant breeding at the Royal Society, at the British Association for the Advancement of Science, as well as at public lectures to farmers, in national newspapers such as The Times and in local ones, such as the Macclesfield Courier, he was enthusiastically received by audiences, readers and editors. His success in changing British agriculture owed much to the fact that many members of these scientific bodies were also senior civil servants in the Board of Agriculture. Figures such Sir Rowland Prothero, Sir Alfred Daniel Hall or Sir Daniel Morris, who moved in powerful circles both in government and outside it, or Sir Thomas Hudson Middleton or Thomas Barlow Wood, whose careers ran from Cambridge to Whitehall and back again, lent much help and support to Biffen's cause. ${ }^{16}$ Many times, as they recommended further support for Biffen's vision, these men pointed towards his new varieties and their agricultural importance. ${ }^{17}$ This was a delicate balancing act: Biffen felt he should be free to pursue Mendelian experiments without thought for their application but the supposed productiveness of this exercise rested on the usefulness of his new varieties.

Biffen's plans for Britain's agriculture began at the University of Cambridge's Department of Agriculture. From around 1904, he began working on the patterns of inheritance of various characteristics in wheat. Biffen noticed that disease resistance followed a classic Mendelian pattern of inheritance. This meant that the inheritance of disease resistance was, Biffen believed, predictable. Like William Bateson, 
encountered in previous papers in this special issue, Biffen believed he could use knowledge of hereditary patterns to build up pre-planned varieties. In this case, he wanted a disease-resistant strain which he thought he could create by pulling the disease resistance out of one plant and plugging it into another. ${ }^{18}$ This is how, in 1906, Biffen described the new precision created by Mendelism, in an article written for the Journal of the Royal Agricultural Society:

The extraordinary certainty with which the complex problems of heredity can be unravelled has shown that the hopes of a few years ago, that breeding would become a precise subject, are rapidly being realised. ${ }^{19}$

There is a beautiful paradox here: disease resistance is actually, as we now know, much more complicated than this. ${ }^{20}$ Despite, however, starting from oversimplified premises, Biffen succeeded in doing exactly what he claimed Mendelism allowed him to do. In 1910, he released Little Joss, a disease-resistant wheat, built from a cross between an American strain with disease resistance (Club) and a British wheat with high yield (Square Head's Master). ${ }^{21}$

By Biffen's reckoning, Little Joss arose quite fortuitously from his work on modes of inheritance. Even his initial interest in disease resistance had been academic: he had wanted to compare the modes of inheritance of physiological and morphological characters (that is, ones which reflected internal processes, such as nutrition, and those which described external features, such as shape -- a distinction that was subsequently eroded by molecular genetics). Disease resistance was a physiological character that had come to mind as Biffen considered which characters would make good test cases for the new theory. ${ }^{22}$ Indeed, yellow rust, the disease to 
which he bred resistance, was not recognised as a problem by most farmers, but the yellowness of rusted plants made them easy to spot in Biffen's test plots. ${ }^{23}$ As Biffen put it, "[I]mmunity and susceptibility to the attacks of yellow rust form as sharply a differentiated pair of characters as Mendel himself would have wished for". ${ }^{24}$ For Biffen, the economic significance of this work was, at this point, a secondary bonus. The primary conclusion that he, along with Bateson, derived from these early diseaseresistance experiments was that Mendelism could explain a wider range of characters in a wider range of organisms than had previously been recognised. ${ }^{25}$

Nonetheless, Biffen's disease-resistant Little Joss was a celebrated victory. News of the variety was carried by The Times and Daily Mail as well as by a number of local newspapers. ${ }^{26}$ Biffen also did a great deal to promote his views to farmers, and he made many personal appearances at the meetings of farmers' clubs.

Sometimes the discussion at these events would become heated as farmers wanted to know what Biffen could do for them in terms of addressing what they considered to be the more serious problems they faced. ${ }^{27}$ However, there was often someone in the audience who was more than willing to step forward and defend Biffen from such questions. For example, at a meeting of the Bedfordshire Chamber of Agriculture, at the Swan Hotel, Bedford, sometime around 1910, one Mr E. Laxton was there to deflect some tricky questions aimed at Biffen by local farmers:

Mr E. Laxton said he thought the meeting did not recognize the great work that Mr Biffen had been doing for agriculture, but in a few years they would look upon him as one who had added to their incomes. He knew from his own experimental work how immense was the labour and expense of producing new varieties. Mr Biffen was devoting his life and brains to bringing out new 
wheats that would add to the well-being of the country and of the world. Farmers ... could rely on Mr Biffen when he introduced a new variety ... he had no commercial interest. Prof. Bateson, who was a second Darwin, had the greatest confidence in Mr Biffen's work. ${ }^{28}$

This impassioned defence of Biffen and his work is significant for the grounds on which Laxton based it (and also because it speaks with such conviction to a promise that was, at that point, still unfulfilled: the economic success of Biffen's varieties). Laxton's claim that Biffen had no commercial interest fits with a general pattern of claiming selfless public service as a motivation, one which has already been noted as an important feature of Biffen's interaction with the moral economy of plant breeding. Here, Laxton went one step further, claiming Biffen's financial disinterest was guaranteed, not only because of his moral character, but also by his scientific credentials. In other words, Biffen's conception of the relationship between science and agriculture was not only more likely to yield results, but it also guaranteed the degree to which farmers could trust him.

In 1910, Biffen and his colleagues at the newly upgraded School of Agriculture at the University of Cambridge petitioned the government, through their contacts at the Board of Agriculture, to extend funding for Biffen's work by establishing a plant breeding institute. ${ }^{29}$ After some negotiation, the new institute was housed on the farm next door to the School's, and Biffen was made its first Director. The funding came from the Exchequer via a recently appointed body called the Development Commission. In 1910, and despite the defeat of his People's Budget, Chancellor of the Exchequer David Lloyd George made nearly £1million available for distribution by the Commission; this figure would grow significantly over the years. 
Headed by Biffen's sometime collaborator in breeding, A. D. Hall, the Commission cited the success of Little Joss as justification for its expenditure of around $£ 9,000$ on Cambridge's Plant Breeding Institute. ${ }^{30}$

From this new institutional position Biffen continued his work on strength. The Times frequently published news of Biffen's work, and, in 1914, as the probable onset of war focused minds on the question of food supply, Biffen authored an account of his work as part of a special focus section on the wheat industry. He explained that the wheat plant had reached its yielding limit—higher yields could only be achieved by better cultivation — and consequently the only way to increase prices, and so the relative level of home production, was to increase the quality of British wheat. The prospects of doing so were, however, good:

The results described show that in practice it has proved possible to add something to the quality and yield of wheats grown here. The experimental results are still more promising, and we can reasonably expect, especially now that the rate of consumption is again catching up the supply, that increasing profits will lead to an increase in our English wheat area. ${ }^{31}$

In this line of research, instead of seeking to avert losses, Biffen, using Mendelian theory, set about producing a new wheat variety that would increase farmers' profits directly by protecting them from foreign imports.

Biffen reasoned that, if he could transfer disease resistance from plant to plant, he could do the same with strength: he could transfer the quality of strength from American to British wheat. Once again, Biffen succeeded, despite his principal assumption - that strength was a simple Mendelian character-being at best 
contentious and at worst wrong. ${ }^{32}$ In 1916, Biffen released Yeoman, a cross between a strong wheat and a high yielding British wheat. He hoped that the new strong wheat would increase the amount of home-grown wheat that inland millers could use in the production of bread flour. Increasing home consumption would reduce the strategic advantage of port millers with their easy access to imports, and allow rural mills and the surrounding wheat growing areas to flourish once more, as the price of British wheat increased along with its quality. At the same time, Britain would become less reliant on imports.

In relaxed mode, after the War, in 1918, when talking to Harold Begbie, a journalist for the Daily Chronicle and The Globe, Biffen linked up his beliefs about nation and wheat. Here we find him evoking a clear picture of a rural civilisation supported by a thriving wheat industry. The article is a promotional piece for a new National Institute of Agricultural Botany, an institute Biffen wanted as a distribution centre for his new varieties. It begins with a call to revolution:

We have got to tune up farming. The farmer is now alert and receptive. The Board of Agriculture is alive to the possibilities of the future. If only the national spirit gets aroused we may accomplish great things. It is not at all impossible that we may create in England a great rural civilisation. That would be a most beneficent revolution.

Begbie added his own thoughts on the need to establish a National Institute of Agricultural Botany which would conduct plant breeding, trialling, regulation and distribution: 
No seed merchant can do what this National Institute would undertake. It is unreasonable to expect the seed merchant to conduct experiments over eight or ten years, subject each step in his process to milling and baking tests, corresponding with men of science all over the world, even in Tibet, as Professor Biffen does, when at the end of it all there is nothing patentable. A seed once on the market is everybody's property. The seedsman has done good and patriotic work but we must not expect too much of him. ${ }^{33}$

One of Biffen's many supporters in these plans was Sir Daniel Morris. A prominent Mendelian in his own right and a well-connected agricultural agitator, Morris shared much of Biffen's thinking on the moral imperative to systematise agriculture. Morris began his career working on sugar cane cultivation in the West Indies for the British government. He is perhaps most famous for turning around the fortunes of the Royal Horticultural Society but he also maintained strong links with government and often participated in the meetings of the British Association for the Advancement of Science. ${ }^{34}$ In 1907, at the Royal Horticultural Society's third conference on genetics and plant breeding, he explicitly described Biffen's work as a model to be emulated in sugar cane breeding, "Further", said Morris, "the work of Biffen with wheat-breeding should serve as a model on which breeding of sugar cane should be carried on."35 Some years later, again speaking to the British Association for the Advancement of Science, Morris pointed to the need for new institutional support to be provided to Biffen by the National Institute of Agricultural Botany: "The establishment of a National Institute of Agricultural Botany for the further development of plantbreeding and the distribution of pure seed may be regarded as essential to the welfare and safety of the nation."36 
In 1921, the National Institute of Agricultural Botany (NIAB) officially opened the doors of its purpose-built premises with a visit from the king and queen. ${ }^{37}$ The institute was located on the opposite side of the Huntingdon Road from Biffen's Plant Breeding Institute, on the outskirts of Cambridge; both were five minutes' walk from Biffen's home at 138 Huntingdon Road. The new institute was intended to aid Biffen in his plant breeding, to provide testing of the agricultural merits of new varieties, and to take care of their distribution. Furthermore, NIAB would house an Official Seed Testing Station which would regulate seeds already on the market, testing their viability and identity. David Lloyd George, now at the end of his second term as coalition prime minister, enthusiastically supported the institute and its developing plans for releasing commercial varieties. In 1922 he wrote an open letter to The Times, addressed to the institute's founder Sir Lawrence Weaver:

Dear Sir Lawrence. - I have been following with great interest the rapid progress of the National Institute of Agricultural Botany, and congratulate you and your colleagues on the serious and useful work the Institute is already doing for the farming community... I gladly show my appreciation of what you are doing by asking to be enrolled as one of the first Life Fellows of the Institute. $^{38}$

Other notable life fellows of the institute, a body set up to attract prestige, funds and support, included William Bateson and Wilhelm Johansson, the Danish scientist responsible for developing pure-line theory.

Biffen's plans for plant breeding and its institutional support in Britain received widespread coverage and met with much success. His varieties were widely 
grown and by the mid-1920s he was at the head of a wide-ranging empire of institutions. Biffen also left a legacy of concern for these issues in his home institutions, the Cambridge School of Agriculture, NIAB and the Plant Breeding Institute. One of the key figures in fostering this legacy was Biffen's student Frank Engledow, who went on to fill the chair of agriculture at the Cambridge School of Agriculture. In Nature's obituary of Engledow, his outstanding contribution was considered to be to the Empire, in particular his work "to perfect a course of postgraduate training for those destined for the agricultural services in the Colonial Territories, and so provide the personnel for the implementation of policies recommended by the Commissions on which he served." ${ }^{39}$ This paper now turns from the problems posed by the international context to the resources it could offer for their solution.

\subsection{The Other Grain Invasion}

Mendelism was embedded in an international context, one rarely acknowledged in the nation-specific histories of genetics currently available. ${ }^{40}$ Biffen's strains of wheat were constructed using materials from around the world. For example, Little Joss, Biffen's first success, was derived from American and English varieties. Equally, much of the groundwork for his second success, Yeoman, involved the testing of American, Hungarian and Russian varieties. ${ }^{41}$

In the early years of his career, Biffen placed himself at the heart of an international network of knowledge and seed exchange. This included, at one time or another, William Jasper Spillman in America, William Farrer in Australia, William Balls in Egypt, William Backhouse in Argentina, and Robert Heath Lock and Albert

Howard in India. ${ }^{42}$ Biffen also kept in touch with Charles Hurst and William Bateson 
in Britain and each of these Mendelians kept up their own networks of correspondence and material exchange which they shared with him. ${ }^{43}$ Biffen's correspondents swapped seeds and information with him and many of his students took seeds with them when they left Cambridge. This widespread network of researchers also conducted trials and experiments for each other. This allowed Biffen to test the effects of different environmental conditions on the characters he was following in his crosses. In these tests his chief concern was with the transmission of characters: if, as he believed, Mendelism accurately described the transmission of disease resistance in Britain, would the same hold true in India? As Biffen's empire in British agriculture expanded, he increasingly gained access to foreign plant materials and his students found themselves in better funded jobs. His financial resources were never enough, especially in comparison to those at the disposal of his American counterparts, but, with the help of several former students, now working in research stations around the world, Biffen was able to harvest materials from a wide range of sources. He joked of one particularly complex cross, "By the time this has been accomplished perhaps the League of Nations will be able to turn its attention to deciding what nationality the new wheat is." ${ }^{44}$ With the foundation of the National Institute of Agricultural Botany these informal networks were consolidated and extended. In the 1920s, Biffen's fame was widespread and his name, along with the new institute's, further encouraged correspondents to send in samples. The plot manager at NIAB kept records of its acquisitions, which recorded varieties coming from as far afield as Poland, Nigeria and even the Everest expeditions of the 1920s. ${ }^{45}$ The Daily Mail described this network explicitly, in the 1930s, in a piece celebrating some of Biffen's achievements: 
From the Cambridge station wide-spread research is directed. One research worker is testing rust-proof varieties from Canada in order to see whether they will be susceptible to the yellow form. In the Argentine, in Australia, in Kenya Colony, and in Germany Cambridge students are conducting experiments for the man who guided their studies in the earlier days; indeed there is no part of the world in which people anxious to carry out research cannot receive direction and inquiry from the experimental station. ${ }^{46}$

In terms of Biffen's plans for British agriculture, the rest of the world was a mixed blessing. On the one hand, the grain invasion represented a threat to British wheat farmers, unable to compete on costs or quality with foreign imports and this was a problem against which Biffen framed the productive value of his work. On the other hand, Biffen's research depended on his access to varieties of wheat which possessed the characters he wanted to use in his breeding programs. The position of Britain's colonies adds an interesting layer of complexity to this picture, not least because the resources available in the colonies suggested a way forward for ensuring Britain's food security and placing the country at the heart of a new golden age of colonial prosperity.

\section{The Agricultural Empire}

\subsection{British Colonial Agriculture and the International Wheat Markets}

If we return to Biffen's interview with Harold Begbie, we see that it ended with an appeal to the lost greatness of Britain, a greatness that, Biffen believed, could be recaptured through the sort of revolution in plant breeding he advocated. Yet, considering Biffen's emphasis on the importance of science and progress, the image 
he presented is a curiously backward-looking one, seeking, as it did, to capture and restore something of a supposed lost greatness: ${ }^{47}$

London, says our professor, is still the world's chief emporium of the seed trade; very few people know that fact, an important fact; and yet nothing is done on a scale commensurate with this position to improve the quality of our seed. Sweden is far more go-ahead than we are. We ought to wake up to the duty laid upon us by our position as the centre of the greatest agricultural empire in the world. We can give a new impetus to the national life, establish a new stability, if only we give our minds to the business. ${ }^{48}$

In other words, Biffen believed that what the country needed to create a new social stability was a revolution in agriculture, one that would change agriculture in both Britain and the colonies.

In 1918, at around the time he was interviewed by Begbie, Biffen also appeared as star witness before one of the government's post-war reconstruction committees. The Selborne Commission was instigated by the Board of Agriculture and Fisheries under the terms, "To consider and report on the methods of effecting an increase in the home production of food supplies, having regard to the need of such an increase in the interests of national security." adoption of surprisingly far reaching powers for the government to intervene in British farmers' fields, if it was deemed that land was being wastefully used for "game or games". Despite this very national focus, Biffen's evidence rested largely on a summary of global wheat production. Britain's problem, Biffen explained, was the US and Canadian imports that had flooded the market. He proceeded to give a 
summary of wheat growing in Argentina, Russia, India and Australia, all countries which provided sources of cheap wheat. Cheap wheat had driven down prices and with it the acreage farmers were willing to use for wheat growing. However, there was, Biffen reckoned, some hope that the situation would soon change:

It may be assumed that the course of events in America will prove typical of that of other countries where there has been a rapid rise of production under prairie conditions. The soils gradually become exhausted and in place of continuous wheat cultivation a system of rotation has to be adopted. ${ }^{50}$

In other words, the grain invasion would soon dry up and consumption would once again outstrip global production. Aside from waiting out the storm, Britain's best hopes for rejuvenating its wheat growing industry lay in three directions, improved varieties, more intensive production and an increase in the wheat growing area. Of these options, Biffen was most hopeful about the first, improved wheat varieties:

Increased production may be expected from any improvement in the kinds of wheat grown. ... of late the systematic study of cross-breeding has opened up great possibilities of improvement. ${ }^{51}$

Of course, if improved wheat varieties could aid British agriculture, they could also do the same in the colonies. Establishing agriculture (and favourable trade links) in the colonies would, Biffen hoped, increase Britain's food security. Cotton from Egypt, wheat from India, and rubber and sugar from the West Indies were already 
established crops which could be tuned up. For Kenya the plans of the new agriculturalists were somewhat more ambitious.

\subsection{Sir Rowland Biffen in Kenya}

Colonies such as Kenya had virgin soils, which for one reason or another had never been used for wheat production on a large scale. It was hoped by many, both in Kenya and Britain, that wheat could be introduced alongside the plantation crops of coffee and sisal and the staple food crop of maize. As we shall see in this section, Biffen was at the forefront of the campaign to establish wheat growing in Kenya in the belief that a similar institutional empire to his own in Britain could be established in the colony and similar dreams of rural civilisation and stability realised.

Biffen's involvement with the British empire endured throughout his career. His star student and obituarist, Frank Engledow claims that Biffen became an agricultural scientist after an inspiring research trip to study colonial agriculture in the West Indies. ${ }^{52}$ Even after Biffen had officially retired from academic life, for many years he remained involved with the Imperial Agriculture Bureau. His second trip to the colonies, this time as a knight of the realm rather than an awed student, was to Kenya in 1926 . He had been asked by the colonial administration to investigate the colony's prospects of establishing wheat farming; it was something its European settlers had been calling for, for some time. ${ }^{53}$

The problems in Kenya which Biffen recorded were quite different to those in Britain. Biffen's remit was to assess claims by Kenyan settlers that wheat could be grown productively. It seems that some farmers did very well with wheat crops, but overall there were two problems, one geographical and one pathological. The topographical map of Kenya (reproduced in figure 1) shows the geographical situation 
that would-be wheat farmers had to deal with. Kenya can loosely be divided into two areas, a fertile mountainous region (in the west), and a large area of low lying and drought-prone land that was less suitable for wheat growing (in the east). Much of the interest in growing wheat in the mountainous area that was suitable for the plant had arisen since the 1910s, when a new railway line was brought to this region, making access far easier.

[insert figure 1 here]

Beyond these geographical constraints, there were pathological hurdles facing Kenyan wheat production. Kenya was home to three types of rust disease. Losses from these rusts could be catastrophic, ruining a whole crop if they took hold. The three varieties, black rust, Puccinia grammis, yellow rust, Puccinia glumarum, and brown rust, Puccinia triticina, were active at different altitudes. Black rust, the most destructive, was prevalent at 4,500 - 6,500 feet, yellow rust was restricted above 6,500 feet, and brown rust grew at any altitude. ${ }^{54}$ A simple solution to the yellow rust problem along the lines Biffen had instigated in Britain with Little Joss would not be enough to overcome a three-way pathogenic threat.

Despite the problems facing Kenyan wheat farmers, Biffen was hopeful. In his speech to the Kenyan farmers in 1927, Biffen claimed that the only way to progress was by increasing support for Kenyan research stations, similar to his own in Britain. Granted such support, the prospects would be better. At the end of his trip, Biffen published the results of his observations and his recommendations in a report produced by the Kenyan administration. This forty-page booklet begins with a general survey of extant attempts at wheat growing. The area on which wheat was cultivated 
had been steadily expanding. Biffen attributed this to access provided by the new railway line and the breaking of new, fertile land in the process. Demand for wheat, Biffen supposed, was also increasing as the "native population is beginning to make use of wheaten food-stuffs." ${ }^{, 55}$ Increases in local demand, he reckoned, could only benefit the white settlers who tried wheat farming.

In accordance with the terms on which he had been invited to Kenya, that is, to report on the wheat industry "with particular reference to the methods of plant breeding now in progress and the organisation of an extended service in the future", Biffen's recommendations were heavily in favour of extending the institutional basis of plant breeding. ${ }^{56}$ His first recommendation was the creation of a permanent post of government plant breeder. This position had only been occupied on a temporary basis in previous years and, while there had been some success, in order to expand this work Biffen believed there should be someone working in the post continuously and preferably aided by an assistant.

Biffen saw the other key to answering Kenya's problems-with the three different types of rust-in changing the situations of the research stations at which plant breeding was conducted. At the time, Kenya had three plant breeding research stations: Scott Agricultural Laboratories, just outside Nairobi, and two others, one at Njoro and one at Gilgil. Biffen recommended that the centre of plant breeding activity should be moved from its current position in Nairobi to the Njoro station, which was situated at around 7,000 feet. This altitude would allow researchers to investigate resistance to all three varieties simultaneously. The institutional reshuffle required would be expensive but, Biffen hoped, through the sale of new varieties it could eventually pay for itself. ${ }^{57}$ 
Once again Biffen's work appeared in The Times, which published a short article on his report on Kenya including its main claim, that, "the hope that Kenya can supply itself and its neighbours is realizable." ${ }^{58}$ The Times article also set Biffen's report in the context of a new census of Kenyan agriculture. The figures show the scale of wheat production as $9 \%$ of the area under cultivation by white settlers, with coffee and sisal each as $14 \%$, and maize as $41 \%$. In the years after Biffen's visit, however, and despite a follow-up visit by A. D. Hall, settlers rarely accepted his invitation to expand wheat cultivation further, as they found they could make far more money from growing coffee, especially if they barred the natives from doing the same and thereby eliminated their competition. Biffen's plans for wheat production failed to materialise and the Scott Agricultural Laboratories remained the centre for agricultural research in Kenya (renamed sometime later as The National Agricultural Research Laboratories).

\section{Concluding Reflections}

The story of the expansion of Biffen's institutional empire in Britain is now quite well known. What has been shown here for the first time is the extent to which Biffen's work became a feature in the popular press. The support offered by The Times, the Daily Mail and other newspapers must have aided Biffen in his negotiations with civil servants and university staff over access to space and resources. This is the nub of the IP issue at hand in this paper. Whether Mendelism was successful or not, it was Biffen's productivity claims made-using the machinery of promotion of an earlier generation of plant breeders-on the behalf of Mendelism which mattered. Biffen might not have taken out any patents on his new varieties but he certainly traded on this item of socially constructed intellectual property, the belief (as espoused by 
Laxton) that Mendelism could and soon would be used productively. Biffen's motivation was ostensibly the good of the nation but his mode of action shares more than a passing resemblance with that of the traditional inventor, demanding some form of favouritism because of the promises his new invention, once revealed, held out for national wellbeing.

Recognising the popular, contemporary Mendelism-will-revolutionise-plantbreeding narrative need not stop us, however, from asking how much Mendelism actually mattered in Biffen's breeding programmes. Indeed, Engledow and Bateson have already answered this question to some extent: in their view, Biffen was more of an artist than his popular presentation would suggest (although Biffen's often repeated moniker of 'Wheat Wizard' hints at this). However, being distracted overly by such questions detracts somewhat from the solidity of Biffen's and his supporters' plans. Whatever role Mendelism might actually have played in the development of plant breeding, its perceived role was far more important for Biffen's wider aspirations. Plant breeding was important to Biffen, but it was part of a grander scheme for changing the whole system of agricultural production.

Mendelism was deployed as a national science that would place Britain on a better global footing in terms of its food security. Biffen's claim that it could rescue the British wheat industry from international competition was an oft-repeated article of faith in the corridors of the Ministry of Agriculture. Mendelism was also deployed as a science of empire and this can be seen in Biffen's claims that it could revolutionise agriculture in the colonies, the agricultural empire. This paper has made it clear that Mendelism operated on an international level, responding to international threats but also drawing on international resources, which were sent back to Britain by Biffen's correspondents. Furthermore, Biffen's story is not an isolated one: 
Mendelians, and especially agricultural Mendelians, travelled a lot. A very similar story to Biffen's could be told of Sir Daniel Morris and his work with sugar cane, or William Backhouse working with wheat in Argentina or, indeed, Robert Lock working with rubber in Ceylon. This paper suggests the need to recognise that Mendelism operated across a range of geographical units. At present, there are several excellent national studies of the history of Mendelism available and fewer national comparative studies. This paper builds on this work, to recognise the links between countries on an international scale, in this case between Britain and the international wheat markets in general and, specifically, between Britain and Kenya.

\section{Acknowledgements}

An earlier version of this paper was presented at the Owning and Disowning Invention Conference held in Leeds in 2010. I would like to thank the participants of the conference for several helpful suggestions as to how to develop the paper. My colleagues in the Arts and Humanities Research Council-funded project, Owning and Disowning Invention, and especially my PhD supervisor, Gregory Radick, and his coeditor for this volume Christine MacLeod, have also provided insightful feedback on previous drafts and much help in shepherding this paper through the publication process. I gratefully acknowledge the support of the UK Economic and Social Science Research Council (ESRC) as extensive revisions were made to this paper while working at the ESRC Centre for Genomics in Society (Egenis) at the University of Exeter, UK. Finally, I would like to thank Mario Biagioli and Jonathan Harwood for reviewing this paper prior to publication and providing comments and feedback which have no doubt made it stronger. All remaining errors are, of course, my own. 


\section{References}

Anderson, G. [1899]. The revival of English agriculture. London: Jarrold \& Sons.

Bateson, W. (1902). Practical aspects of the new discoveries in heredity. In L. Barron (Ed.), International conference on plant breeding and hybridisation, 1902 (pp. 1-9). New York: Horticultural Society of New York.

Bateson, W. (1909). Mendel's principles of heredity. Cambridge: Cambridge University Press.

[Begbie, Harold], [1918]. H. B., Professor Biffen: The idea of a rural civilisation. In Extracts from newspapers on wheat research of Professor Sir Rowland Biffen MA FRS, Cambridge University, Rowland Biffen Papers, John Innes Centre Archives, p. 1.

Bell, G. D. H. (1986). Frank Leonard Engledow, 20 August 1890 - 3 July 1985. Biographical Memoirs of Fellows of the Royal Society, 32, 189-219.

Biffen, R. H. (1903). Experiments on wheat. Nature, 69, 92-93.

Biffen, R. H. (1905). Mendel's laws of inheritance and wheat breeding. Journal of Agricultural Science, 1, 4-48.

Biffen, R. H. (1906). The application of Mendel's laws of inheritance to breeding problems. Journal of the Royal Agricultural Society of England, 67, 46-63. 
Biffen, R. H. (1907a). Modern plant breeding methods: With special reference to the improvement of wheat and barley. Science Progress, 1, 702-722.

Biffen, R. H. (1910a). The inheritance of "strength" in wheat. Journal of Agricultural Science, 3, 86-101.

Biffen, R. H. (1914). British wheat: Improved methods of cultivation: Increased home supply. The Times, 8 June 1914, p. 16 b-c.

Biffen, R. H. (1910b). Correspondence: The inheritance of "strength" in wheat. Journal of Agricultural Science, 3, 223-224.

Biffen, R. H. (1924a). Modern wheats. Journal of the Farmers Club, 1, 1-18.

Biffen, R. H. (1925). Making new wheats. Cambridge University Agricultural Society Magazine, 1, 19-23.

[Biffen, R. H.] (1926). Wheat growing in Kenya. East African Farm and Home Journal, December 1926, p. 3. Reprinted in Extracts from newspapers on wheat research of Professor Sir Rowland Biffen MA FRS, Cambridge University. Rowland Biffen Papers, John Innes Centre Archives.

Biffen, R. H. (1927a). Report on wheat production in Kenya. Nairobi: Government Printer. 
[Biffen, R. H.] (1927b), Future of Wheat Growing in Kenya. The Times, $22^{\text {nd }}$ January $1927,11 \mathrm{~g}$.

Biffen, R. H. and Humphries, A. E. (1907). The improvement of English wheats. Journal of Agricultural Science, 2, 1-16.

Board of Agriculture and Fisheries (1918). [Cd. 8506] 1917-18: Report of the Agricultural Policy Sub-Committee of the Committee on Reconstruction, appointed to consider the methods of effecting an increase in the home-grown food supplies, Part I. London: HMSO.

Brock, W. (2008). William Crookes (1832-1919) and the commercialization of science. Aldershot: Ashgate.

Charnley, B. (2011). Agricultural science, plant breeding and the emergence of a Mendelian system in Britain, 1880-1930. Unpublished PhD, University of Leeds.

Charnley, B. (forthcoming, 2012). Seeds without patents: Science and morality in British plant breeding in the long nineteenth century," Revиe Economique.

Charnley, B. and Radick, G. (2010). Plant breeding and intellectual property before and after the rise of Mendelism: The case of Britain. In D. J. Kevles, H. J. Rheinberger and J-P. Gaudillière, (eds), Living properties: Making knowledge and controlling ownership in modern biology ( pp. 51-55). Berlin: MPIWG Preprint. 
Collins, E. J. T. and Thirsk, J. (Eds.), (1967-2000). The agrarian history of England and Wales, 8 vols. Cambridge: Cambridge University Press.

Crookes, W. (1899). The wheat problem: Presidential address," Report of the sixty sixth meeting of the British Association for the Advancement of Science; Held at Bristol in September 1898.

Crookes, W. (1917). The wheat problem. London: Longmans, Green and Co.

Dale, H. E. (1956). Daniel Hall: Pioneer in scientific agriculture. London: John Murray.

Engledow, F. L. (1950). Rowland Harry Biffen, 1874-1949. Obituary Notices of Fellows of the Royal Society, 7, 9-25.

[Engledow, Sir F.] (1957). News and views: Agriculture in the University of Cambridge, Sir Frank Engledow, C.M.G, F.R.S. Nature, 179, 894.

H., F. G. (1931). Obituary notice, Proceedings of the Royal Society of London. Series $B, 108$, i-iii.

Hall, A. D. (Ed.) (1936). English farming past and present (5th ed.). London: Longmans. 
Hynes, S. (1968). The Edwardian turn of mind. Princeton: Princeton University Press.

Kevles, D. J. (1980). Genetics in the United States and Great Britain, 1890-1930: A review with speculations. Isis, 71, 441-455.

[Laxton, E.] [1910]. Bedfordshire Chamber of Agriculture. In Extracts from newspapers on wheat research of Professor Sir Rowland Biffen MA FRS, Cambridge University (p. 2.) Rowland Biffen Papers, John Innes Centre Archives.

Lupton, F. G. H. (1987). History of wheat breeding. In F. G. H. Lupton (Ed.), Wheat breeding: Its scientific basis (pp.51-70). London: Chapman and Hall.

Maat, H. (2001). Cultivating practice: A history of agricultural science in the Netherlands and its colonies, 1863-1986. Dordrecht: Kluwer.

Makanda, D. and Oehmke, J. (1993). Promise and problems in the development of Kenya's wheat agriculture. USAID Staff Papers. USAID.

Mingay, G. E. (2009). Prothero, Rowland Edmund, first Baron Ernle (1851-1937). In Oxford dictionary of national biography. Oxford: Oxford University Press, 2004; online edn, May 2009. http://www.oxforddnb.com/view/article/35624. (Accessed 1 May 2012). 
Morris, Sir D. (1920). Address to the Department of Botany," Report of the eighty seventh meeting of the British Association for the Advancement of science; Held at Bournemouth in September 1919, Section K-Botany, 316-331.

O’Rourke, K. H. (1997). The European grain invasion, 1870-1913. Journal of Economic History, 57, 775-801.

Olby, R. (1990). Rôle de l'agriculture et de l'horticulture britanniques dans le fondement de la génétique expérimentale. In J.-L. Fischer and W. H. Schneider (Eds.), Histoire de la génétique: Pratiques, techniques et théories (pp. 65-81). Paris: ARPEM.

Olby, R. (1991). Social imperialism and state support for agricultural research in Edwardian Britain. Annals of Science, 48, 509-526.

Olby, R. (2000a). Horticulture: The font for the baptism of genetics. Nature Reviews Genetics, 1, 65-69.

Olby, R. (2000b) Mendelism: From hybrids and trade to a science. C. R. Acad. Sci. Paris, Sciences de la vie, 323, 1043-1051.

Olmstead, A. L. and Rhode, P. W. (2007). Biological globalization: The other grain invasion. In T. J. Hatton, K. H. O'Rourke and A. M. Taylor (Eds.), The new 
comparative economic history (pp. 115-140). Cambridge, MA: Massachusetts Institute of Technology Press.

Olmstead, A. L. and Rhode, P. W. (2008). Creating abundance: biological innovation and American agricultural development. Cambridge: Cambridge University Press.

Palladino, P. (1990). The political economy of applied science: Plant breeding research in Great Britain, 1910-1940. Minerva, 28, 446-468.

Palladino, P. (1993). Between craft and science: Plant breeding, Mendelian genetics and British universities, 1900-1920. Technology and Culture, 34, 300-323.

Pauly, P. J. (2007). Fruits and plains: The horticultural transformation of America. Cambridge, MA: Harvard University Press.

Punnett, R. (1905). Mendelism. Cambridge: Bowes and Bowes.

Russell, Sir E. J. (1944). Thomas Hudson Middleton. 1863-1943. Obituary Notices of Fellows of the Royal Society, 4, 554-569.

Saunders, C. E. (1910). Correspondence: The inheritance of "strength" in wheat. Journal of Agricultural Science, 3, 218-222.

Thompson, E. P. (1971). The moral economy of the English crowd in the eighteenth century. Past and Present, 50, 76-136. 
Vernon, K. (1997). Science for the farmer? Agricultural research in England, 190936. Twentieth Century British History, 8, 310-333.

Ward, H. M. (1905). Recent researches on the parasitism of fungi. Annals of Botany, $14,1-54$.

Wilks, Rev. W (1907). Report of the Third International Conference on Genetics. London: Spottiswoode.

Wellington, P. S., and Silvey, V. (1997). Crop and seed improvement: A history of the National Institute of Agricultural Botany 1919 to 1996. Cambridge: NIAB.

Williamson, J. (1974). Late nineteenth-century American development: A general equilibrium history. Cambridge: Cambridge University Press.

Wood, T. (1922). The School of Agriculture of the University of Cambridge," Journal of the Ministry of Agriculture, 29, 223-230 and 298-302.

\section{Endnotes}

\footnotetext{
${ }^{1}$ [Biffen] (1926), p. 3.

${ }^{2}$ Wheat production was first introduced to Kenya with white settlement in the 1890s.

For a brief history, see Makanda and Oehmke (1993).
} 
${ }^{3}$ See, e.g., William Crookes's presidential address to the Bristol meeting of the British Association for the Advancement of Science, Crookes (1899). The speech was reprinted with various addenda and went through three separate editions the last of which appeared in 1917: Crookes (1917). See also Brock (2008), esp. chapter 20.

${ }^{4}$ See Thompson (1971), pp. $80-82$ on the switch to white bread that was already underway in Britain at the end of the eighteenth century.

${ }^{5}$ Radick and Charnley, this volume. On the moral economy of plant breeding see Charnley and Radick (2010) and Charnley (forthcoming, 2012).

${ }^{6}$ As with most depressions, there has been much subsequent debate about how widespread or deep this depression was. However, judging by the slew of concerned surveys published around this period, some people certainly believed the depression to be the worst ever seen. For a contemporary if populist account instigated by the Morning Post see Anderson [1899]. For historical analysis which questions the actual extent and scale of the depression see Collins (2000).

${ }^{7}$ See Hall (1936), chapter 17 and p. 363 on high farming - see also Collins (2000).

${ }^{8}$ See Hall (1936), p. 384 on Scottish dairy farming around London.

${ }^{9}$ On the westward expansion of US and Canadian wheat growing, see Olmstead and Rhodes (2008) and Pauly (2007).

${ }^{10}$ For Biffen's view of this situation see, Biffen and Humphries (1907).

${ }^{11}$ On the underlying patterns of development in global trade, from an American perspective, see Williamson (1974). On the European grain invasion see O'Rourke (1997).

${ }^{12}$ Biffen (1903). 
${ }^{13}$ See Biffen (1905), pp. 4-5.

${ }^{14}$ On Biffen's career and life see Engledow (1950) and on the relationship between science and practice he sought to instantiate see Palladino (1993), esp. pp. 310-312.

${ }^{15}$ See Olby (1990) and (1991) on support from civil servants for Mendelism.

${ }^{16}$ For biographical details on Prothero see Mingay (2009). For Hall see Dale (1956); for Morris, see Olby (2000b), pp. 1045-1046; for Middleton, see Russell (1944); for Wood see H. (1931).

${ }^{17}$ For more on this group's advocacy of Biffen in Parliament and elsewhere, see Charnley (2011), esp. pp. 153, 187 and 239.

${ }^{18}$ On Mendelism's ability to allow breeders to control their crosses so they could effectively "take out" and "put in" characters, see Bateson (1902), p. 2.

${ }^{19}$ Biffen (1906), p. 46.

${ }^{20}$ For the history of wheat breeding since Biffen, see Lupton (1987).

${ }^{21}$ For a high-profile description of these experiments see Biffen(1914), p. 16b-c.

${ }^{22}$ Indeed, Biffen's interest in yellow rust was probably more directly a result of his supervisor, Cambridge based mycologist Harry Marshall Ward's interests than anything else: Ward (1905), p. 37.

${ }^{23}$ On the economic impact of yellow rust, see Biffen (1905), pp. 3-4.

${ }^{24}$ Biffen (1907), pp. 719-720.

${ }^{25}$ Biffen's work with wheat was a highlight of Punnett's multi-edition Mendelism, first published in 1905, Punnett (1905), and Bateson's Mendel's principles of heredity, his second textbook on Mendelism, see Bateson (1909). 
${ }^{26}$ As well as Mary Biffen's scrapbook, now at the John Innes Centre Archive, the staff at NIAB also kept scrap books detailing the wide and varied interest of many newspapers in Biffen's work and agricultural science more generally. These scrapbooks form a large part of the evidence put forward in this paper. Using them as evidence has its advantages and disadvantages: on the one hand, bibliographic notes about which newspapers cutting were taken from, and when, are sometimes sketchy; on the other hand, as these scraps were collected by Biffen's wife and contemporaries, we can assume that to some extent they reflect the news coverage that Biffen himself felt to be noteworthy.

${ }^{27}$ See, e.g., the discussion at the end of Biffen's talk at the London Farmers' Club in 1924, Biffen (1924).

${ }^{28}$ [Laxton], [1910], p. 2.

${ }^{29}$ For an overview of the history of agricultural education at Cambridge, see Wood (1922) and Palladino (1993).

${ }^{30}$ For more on the Development Commission, its aims and the way in which it distributed funds see Olby (1990) and (1991), Palladino (1990) and Vernon (1997).

${ }^{31}$ Biffen (1914), p. 16b-c.

${ }^{32}$ The world famous Canadian wheat breeder Saunders disagreed with Biffen vehemently about whether strength was a simple Mendelian character. See the dispute between the two breeders conducted in the letters pages of the Journal of Agricultural Science in 1912: Biffen (1910a), Saunders (1910), and Biffen (1910b). 
${ }^{33}$ [Begbie] [1918], p. 1. See also the letter from Lawrence Weaver to Harold Begbie, $28^{\text {th }}$ June 1918, thanking him for his high praise for Biffen and his plans: Kew, The National Archives, MAF 33/22.

${ }^{34}$ See Olby (2000a) and (2000b) on the RHS and Sir Daniel Morris.

${ }^{35}$ See Wilks (1907), p. 319.

${ }^{36}$ Morris (1920), p. 319.

${ }^{37}$ Half of the money for the institute came from the Development Commission and the other from private donations. However, over the next decade public funds came to account for more and more of the institute's running costs: Wellington and Silvey (1997).

${ }^{38}$ Letters to the Editor, The Times, 16 January 1922: 4c.

39 [Engledow] (1957), p. 894. See also Bell (1986).

${ }^{40}$ See Kevles (1980) and Maat (2001) for two examples of how this history can be moved beyond national perspectives to cross-national comparison.

${ }^{41}$ Biffen and Humphries (1907).

${ }^{42}$ Unfortunately, Biffen threw away all of his own correspondence. However, there are enough letters, saved by his correspondents, and cross references in the correspondence of other breeders to record the existence of the network.

${ }^{43}$ These networks have convincingly been described as the basis for "the other grain invasion": Olmstead and Rhodes (2007).

${ }^{44}$ Biffen (1925), p. 23.

${ }^{45}$ See the "Register Recording the Receipt of Seeds etc. by the Manager of Field Plots 
Commenced 1922", Council Chamber Library, National Institute of Agricultural Botany Archives.

${ }^{46}$ This description of the international scope of Biffen's work is given in the Daily Mail in late 1930s: Extracts from Newspapers on Wheat Research of Professor Sir Rowland Biffen MA FRS, Cambridge University, Rowland Biffen Papers, John Innes Centre Archives, p. 27.

${ }^{47}$ Samuel Hynes' classic cultural history of the Edwardian period goes some way to explaining the curious dual facing attitude of a period which was characterised by both conservative and progressive cultural currents, often embodied in the same individual as here in Biffen's thinking: Hynes (1968).

${ }^{48}$ [Begbie] [1918], p. 1.

${ }^{49}$ See Board of Agriculture and Fisheries (1918), p. 3.

${ }^{50}$ Ibid., p. 26.

${ }^{51}$ Ibid., p. 27.

52 The notebook Biffen kept on this trip has unfortunately disappeared amongst the library collections at Cambridge University: Engledow (1950).

${ }^{53}$ It is worth remembering that the British Empire endured a great deal longer than one might expect. Kenya only became a crown colony in 1920, and it remained so until $12^{\text {th }}$ December 1963.

${ }^{54}$ Kenya Notebook, Rowland Biffen Papers, John Innes Centre Archives.

${ }^{55}$ Biffen (1927a), p. 7.

${ }^{56}$ Ibid., p. 1. In 1926, Biffen was made a KBE. 
${ }^{57}$ Ibid., pp. 33-35.

58 [Biffen] (1927b), p. 11g.

Figure 1

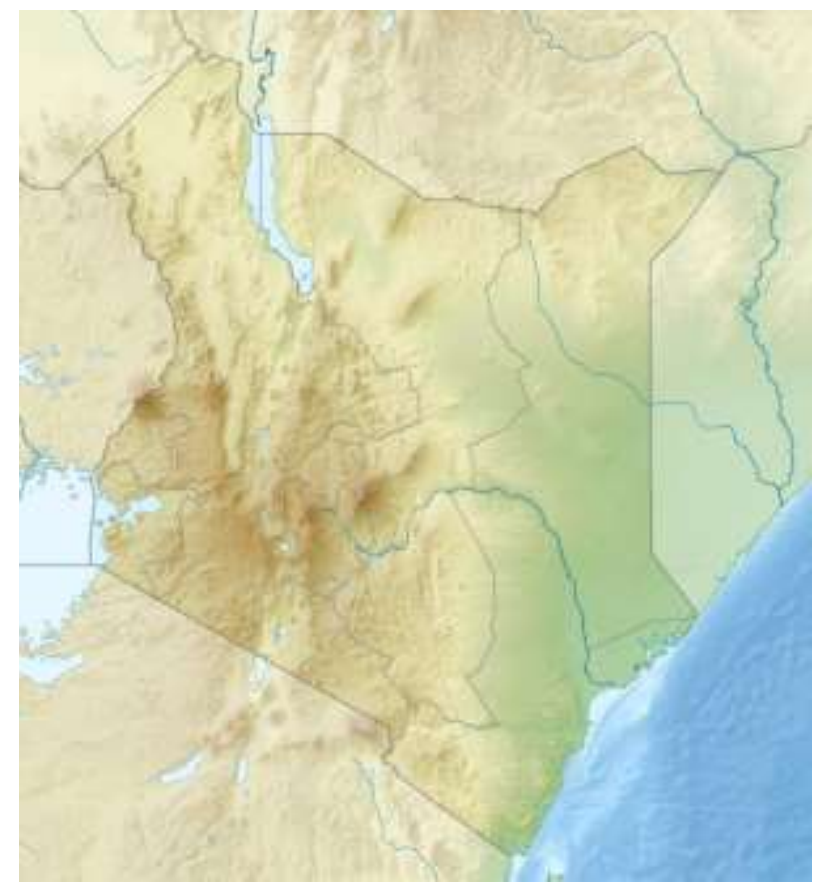

\section{Caption}

Figure 1. Relief map of Kenya showing highland and lowland areas. By Uwe Dedering (Own work).

[CC-BY-SA-3.0 (http://creativecommons.org/licenses/by-sa/3.0) or GFDL (http://www.gnu.org/copyleft/fdl.html)], via Wikimedia Commons. 
